\title{
KUALITAS EGGURT KERING DENGAN BAHAN DASAR SUSU DAN BERBAGAI MACAM BIJI-BIJIAN
}

\section{QUALITY OF DRIED EGGURT PRODUCED FROM A MIXTURE OF MILK AND VARIOUS GRAINS}

\author{
Indratiningsih*, Nurliyani, Rihastuti, Endang Wahyuni, dan Widodo \\ Fakultas Peternakan, Universitas Gadjah Mada, Jl. Fauna No. 3, Bulaksumur, Yogyakarta, 55281
}

\section{INTISARI}

Penelitian ini bertujuan untuk mengetahui sifat kimia, sensoris, dan mikrobiologis produk olahan eggurt yang ditambah tepung biji-bijian. Penambahan tepung biji-bijian dimaksudkan untuk meningkatkan sifat kimia dan sensoris, serta untuk mempertahankan viabilitas bakteri asam laktat (BAL) pada saat pengeringan. Biji-bijian yang digunakan yaitu wijen, kacang hijau, dan kedelai hitam. Eggurt dipersiapkan dengan memfermentasi susu dan putih telur menggunakan 5\% bakteri Lactobacillus bulgaricus dan Streptococcus thermophillus (1:1) dan diinkubasi pada suhu $42^{\circ} \mathrm{C}$ sampai membentuk curd atau $\mathrm{pH}$ mencapai 4,5. Pasteurisasi susu dan putih telur dilakukan secara terpisah. Susu dipasteurisasi pada suhu $85^{\circ} \mathrm{C}$ selama 30 menit, sedangkan putih telur dipasteurisasi pada suhu $63^{\circ} \mathrm{C}$ selama 5 menit. Eggurt kering dibuat dengan mencampur eggurt dengan biji-bijian yang disangrai dan digiling dengan perbandingan 2:1. Setelah eggurt dan biji-bijian dicampur, kemudian dikeringkan pada suhu $50^{\circ} \mathrm{C}$ selama 16 jam diikuti uji kualitas kimia, sensoris, dan mikrobiologis. Hasil penelitian menunjukkan bahwa eggurt-wijen memiliki skor tekstur 47,50, daya terima 43,06, dan total bakteri asam laktat 5,67 log CFU/g yang paling tinggi dibanding eggurt-kedelai hitam dan eggurt-kacang hijau, sedangkan tingkat keasaman 43,85, kadar lemak 9,13\% dan protein 33,06\% yang paling tinggi adalah eggurt-kedelai hitam $(\mathrm{P}<0,01)$. Tidak terdapat perbedaan diantara perlakuan untuk tingkat kemanisan, kadar laktosa, $\mathrm{pH}$, dan derajat keasaman. Hasil penelitian dapat disimpulkan bahwa eggurt-wijen memiliki kualitas sensoris dan mikrobiologis yang paling tinggi, sedangkan kualitas kimia yang paling tinggi diperoleh dari eggurt-kedelai hitam.

(Kata kunci: Kualitas, Eggurt kering, Susu, Wijen, Kacang hijau, Kedelai hitam)

\begin{abstract}
This study aimed to determine the chemical, sensory, and microbiological quality of eggurt that was mixed with various grains of sesame, green bean, and black soybean. The addition of grains starch was intended to improve the chemical and sensory quality, as well as to maintain the viability of lactic acid bacteria (LAB) during drying. Eggurt was prepared by fermented milk and albumen inoculated with 5\% Lactobacillus bulgaricus and Streptococcus thermophillus (1:1) and incubated at $42^{\circ} \mathrm{C}$ to form a curd or the $\mathrm{pH}$ reached 4.5 . Milk and albumen were pasteurized separately. Milk was pasteurized at temperature of $85^{\circ} \mathrm{C}$ for 30 minutes, while the albumen was pasteurized at temperature of $63^{\circ} \mathrm{C}$ for 5 minutes. Dried eggurt was produced by mixing of eggurt and blended grain with a ratio of 2:1, and then dried at $50^{\circ} \mathrm{C}$ for 16 hours. After dried, the eggurt products were then sampled for chemical, sensory and microbiological analysis. The results showed that eggurt mixed with sesame seeds had a highest score on texture (47.50), aceptability (43.06) and total lactic acid bacteria (5.67 log CFU/g) than eggurt mixed with black soybeans and green beans, while eggurt mixed with black soybean had a highest score $(P<0.01)$ on acidity (43.85), fat $(9.13 \%)$ and protein content (33.06\%). There was no different effect between grain sources on degree of sweetness, lactose concentration, $\mathrm{pH}$ and acidity levels. It can be concluded that eggurt-sesame has the best sensory and microbiological quality, while the best chemical quality was obtained from eggurt-black soybeans.
\end{abstract}

(Keywords: Quality, Dried eggurt, Milk, Sesame, Green beans, Black soybeans)

\footnotetext{
* Korespondensi (corresponding author):

Telp.+62 8179403854

E-mail: indrati_sp@yahoo.com
} 


\section{Pendahuluan}

Diversifikasi produk pangan asal ternak seperti susu dan telur telah banyak dikembangkan. Berbagai fortifikasi pangan pendukung kesehatan tubuh telah banyak dilakukan untuk memenuhi standar kesehatan, misalnya dengan penambahan probiotik dan prebiotik, penambahan serat, dan penambahan vitamin tertentu. Fortifikasi pangan juga banyak dilakukan untuk memenuhi selera konsumen seperti rasa asin, manis, dan gurih, rasa buah-buahan, dan coklat dengan menambah atau mengkombinasikan dengan bahan lain, serta masih banyak lagi hasil fortifikasi yang bertujuan untuk meningkatkan kualitas pangan.

Eggurt adalah minuman yang terbuat dari campuran susu dan putih telur yang difermentasi menggunakan bakteri yogurt Lactobacillus bulgaricus dan Streptococcus thermophillus (Cunningham dan Brant, 1984 cit. Stadelman et al., 1990). Penambahan putih telur bertujuan untuk meningkatkan viabilitas bakteri karena putih telur mengandung protein yang tinggi dan juga dapat memberikan cita rasa dan tekstur yang lebih baik daripada yogurt, serta dapat menambah nilai gizi dari minuman tersebut. Jenis minuman ini belum banyak dikenal masyarakat Indonesia, meskipun untuk jenis produk susu fermentasi yang lain sudah banyak dikenal. Minat masyarakat Indonesia akan susu fermentasi masih rendah jika dibandingkan dengan masyarakat di negara-negara Asia yang lain maupun Eropa dan Australia. Di Indonesia, hanya kalangan tertentu yang suka mengkonsumsi susu fermentasi dengan alasan kesehatan dan bukan karena menyukai rasa asamnya. Eggurt yang ditambahkan dengan biji-bijian menjadi makanan kering akan memberikan cita rasa yang berbeda dan nilai gizi yang tinggi. Biji-bijian umumnya mengandung protein dan serat pangan yang tinggi, misalnya biji wijen, kacang hijau, dan kedelai hitam.

Biji wijen (Sesamum indicum L. syn. Sesamum orientalis L.) mengandung 50-53\% minyak nabati, 20\% protein, 7-8\% serat kasar, $15 \%$ residu bebas nitrogen, dan 4,5-6,5\% abu. Minyak biji wijen kaya akan asam lemak tak jenuh, khususnya asam oleat $(\mathrm{C} 18: 1)$ dan asam linoleat (C18:2, Omega-6), 8-10\% asam lemak jenuh, dan sama sekali tidak mengandung asam linolenat. Minyak biji wijen juga kaya akan vitamin E. Ampas biji wijen (setelah diekstrak minyaknya) menjadi sumber protein dalam pakan ternak (Nzikou et al., 2009).

Kacang hijau merupakan salah satu tanaman famili Leguminosa yang popular dan dikonsumsi secara luas di Asia, termasuk Indonesia. Kacang hijau banyak tumbuh hampir di semua tempat di
Indonesia dan mempunyai akses yang sangat luas, serta disukai masyarakat. Ada berbagai jenis makanan (olahan) asal kacang hijau misalnya bubur, minuman, bakpia, gandasturi, dan lain-lain. Kandungan yang ada pada kacang hijau per $100 \mathrm{~g}$ adalah protein $24 \mathrm{~g}$, lemak 1,3 g, karbohidrat $56,7 \mathrm{~g}$, kalsium $124 \mathrm{mg}$, fosfor $326 \mathrm{mg}$, vitamin B1 0,47 $\mathrm{mg}$, dan vitamin B2 0,39 mg (Dadan, 2009), air 10 g, dan kalori 395 kal (Suprapto, 1992 cit. Susanto dan Saneto, 1994). Kelompok kacang-kacangan, disamping merupakan sumber protein dan lemak, juga sebagai sumber vitamin, mineral, dan serat yang baik (Astawan, 2009). Kacang hijau salah satu kelompok kacang-kacangan yang mengandung protein tinggi, tetapi rendah lemak. Kandungan protein kacang hijau mencapai $24 \%$ dan mengandung lemak nabati yang rendah (Anonimus, 2009).

Kedelai adalah salah satu tanaman polongpolongan yang menjadi bahan dasar banyak makanan dari Asia Timur, seperti kecap, tahu, dan tempe. Secara garis besar, kedelai dibedakan menjadi kedelai kuning dan kedelai hitam. Di Indonesia, kedelai menjadi bahan makanan seharihari, khusus untuk kedelai hitam lebih banyak digunakan sebagai bahan baku kecap. Meskipun tidak sepopuler kedelai kuning, kedelai hitam (Glycine soja) menyimpan beragam manfaat untuk kesehatan dan diincar peneliti gizi dan kesehatan. Secara umum kedelai hitam mempunyai kandungan protein yang bervariasi antara $37-41 \%$, karbohidrat 29\%, serta lemak $11-12 \%$, juga mengandung vitamin dan mineral sebanyak $7 \%$ dan abu $6 \%$. Kandungan asam amino glutamate pada kedelai hitam juga sedikit lebih tinggi daripada kedelai kuning, karena itu rasa kedelai hitam lebih gurih dibandingkan kedelai kuning (Anonimus, 2010).

Aplikasi penggunaan biji-bijian dalam pengolahan susu fermentasi perlu dilakukan untuk meningkatkan nilai gizi produk terutama protein dan tingkat kesukaan konsumen terhadap produk susu fermentasi, serta menjaga viabilitas bakteri selama pengeringan. Oleh karena itu, penelitian ini bertujuan untuk memodifikasi eggurt dan berbagai biji-bijian terhadap sifat kimia, sensoris, dan mikrobiologis produk olahan eggurt.

\section{Materi dan Metode}

\section{Pembuatan eggurt}

Eggurt dipersiapkan dengan memfermentasi susu yang ditambah $10 \%$ putih telur menggunakan 5\% bakteri Lactobacillus bulgaricus dan Streptococcus thermophillus (1:1) dan diinkubasi pada suhu $42^{\circ} \mathrm{C}$ sampai membentuk curd atau $\mathrm{pH}$ mencapai 4,5. Pasteurisasi susu dan putih telur dilakukan secara terpisah. Susu dipasteurisasi pada suhu $85^{\circ} \mathrm{C}$ selama 30 menit, sedangkan putih telur di- 
pasteurisasi pada suhu $63^{\circ} \mathrm{C}$ selama 5 menit untuk menginaktifkan zat antibakteri dalam putih telur.

\section{Pembuatan eggurt biji-bijian kering}

Eggurt biji-bijian kering dibuat dengan mencampur eggurt dengan biji-bijian yang disangan dan diblender. Biji-bijian yang digunakan yaitu wijen, kacang hijau, dan kedelai hitam. Perbandingan antara eggurt dan biji-bijian adalah 2:1. Setelah eggurt dan biji-bijian dicampur, kemudian dikeringkan pada suhu $50^{\circ} \mathrm{C}$ selama 16 jam. Parameter yang diamati adalah uji sensoris oleh 25 panelis tidak terlatih menggunakan tingkatan skor yang meliputi kemanisan, keasaman, tekstur, dan daya terima (Tamime dan Robinson, 1999), sifat kimia yang meliputi kadar air, protein, lemak, dan laktosa (AOAC, 1970 cit. Sudarmadji et al., 1984), serta kualitas mikrobiologis yang meliputi total BAL menggunakan metode Total Plate Count (TPC) pada MRS agar (Rybka dan Kailasapathy, 1996). Parameter lain yang diamati adalah nilai $\mathrm{pH}$ dan keasaman.

\section{Analisis data}

Penelitian dilakukan dengan 3 (tiga) ulangan untuk setiap perlakuan. Data uji sensoris dianalisis menggunakan uji Kruskal-Wallis $\mathrm{H}$, data uji kualitas kimia dianalisis menggunakan analisis variansi pola searah, dan data uji mikrobiologis dianalisis menggunakan analisis variansi pola faktorial (Astuti, 1980), menggunakan SPSS versi 12 for windows.

\section{Hasil dan Pembahasan}

Biji-bijian yang digunakan dalam pembuatan eggurt adalah wijen, kedelai hitam, dan kacang hijau yang disangrai dan digiling dengan ukuran 40 mesh. Hasil analisis proksimat ketiga biji-bijian sangrai tersebut tersaji pada Tabel 1. Berdasarkan hasil analisis proksimat biji-bijian sangrai tersebut, dapat diketahui bahwa kedelai hitam memiliki kadar protein, lemak, dan serat tertinggi jika dibandingkan dengan wijen dan kacang hijau. Nilai gizi biji-bijian ini akan mempengaruhi kualitas kimia, sensoris, dan mikrobiologis pada eggurt kering yang ditambah dengan biji-bijian tersebut. Tepung biji-bijian ini ditambahkan dengan tujuan untuk menjaga viabilitas bakteri dengan meningkatkan struktur pangan ketika proses pengeringan, meningkatkan nilai gizi dan meningkatkan kualitas sensoris eggurt kering.

\section{Sifat kimia}

Sifat kimia ditentukan oleh nilai gizi bahan dasar yang digunakan untuk pembuatan eggurt. Komponen kimia tersebut akan mempengaruhi kualitas sensoris produk pangan. Tabel 2 menunjukkan bahwa eggurt-kacang hijau kering mengandung air $28,51 \%$, lebih tinggi $(\mathrm{P}<0,01)$ jika dibandingkan dengan eggurt-wijen $(20,88 \%)$. Hal ini menunjukkan bahwa kacang hijau mempunyai kemampuan mengikat air lebih tinggi jika dibandingkan dengan wijen. Kandungan protein yang terdapat pada bahan pangan baik secara kualitas maupun kuantitas

Tabel 1. Hasil analisis proksimat biji wijen, kedelai hitam, dan kacang hijau yang disangrai (proximat analysis of grains of sesame, black soybeans, and green beans)

\begin{tabular}{lccccc}
\hline \hline \multicolumn{1}{c}{ Biji-bijian (grains) } & $\begin{array}{c}\text { Air (\%) } \\
(\text { water (\%)) }\end{array}$ & $\begin{array}{c}\text { Protein (\%) } \\
\text { (proteins (\%)) }\end{array}$ & $\begin{array}{c}\text { Abu (\%) } \\
(\text { ash (\%)) }\end{array}$ & $\begin{array}{c}\text { Lemak (\%) } \\
(\text { fat (\%)) }\end{array}$ & $\begin{array}{c}\text { Serat (\%) } \\
\text { (fibre (\%)) }\end{array}$ \\
\hline Wijen (sesame) & 4,322 & 22,372 & 1,639 & 13,205 & 1,642 \\
Kedelai hitam (black soybeans) & 5,948 & 38,784 & 4,504 & 15,168 & 4,534 \\
Kacang hijau (green beans) & 2,329 & 27,377 & 5,850 & 1,211 & 2,512 \\
\hline
\end{tabular}

Tabel 2. Rerata hasil analisis sifat kimia eggurt biji-bijian kering (\%) (the average of chemical composition of dried grain egghurt (\%))

\begin{tabular}{lccc}
\hline \hline Kadar (concentration) & $\begin{array}{c}\text { Eggurt-wijen } \\
\text { (sesame egghurt) }\end{array}$ & $\begin{array}{c}\text { Eggurt-kedelai hitam } \\
(\text { back soybean egghurt) }\end{array}$ & $\begin{array}{c}\text { Eggurt-kacang hijau } \\
\text { (green egghurt) }\end{array}$ \\
\hline Air (water) & $20,88^{\mathrm{a}}$ & $24,46^{\mathrm{ab}}$ & $28,51^{\mathrm{b}}$ \\
Protein $($ proteins) & $23,46^{\mathrm{b}}$ & $33,06^{\mathrm{c}}$ & $21,64^{\mathrm{a}}$ \\
Lemak (fat) & $8,82^{\mathrm{b}}$ & $9,13^{\mathrm{b}}$ & $6,63^{\mathrm{a}}$ \\
Laktosa (lactose) & 3,04 & 2,80 & 2,91 \\
${ }_{\mathrm{a}, \mathrm{b}, \mathrm{c}}^{\mathrm{n}}$ Superskrip yang berbeda pada baris yang sama menunjukkan perbedaan $(\mathrm{P}<0,01)($ different superscripts \\
at the same row indicate significant differences $(P<0.01))$. & \\
ns &
\end{tabular}


berpengaruh pada daya serapnya terhadap air (MacRitchie, 1984 cit. Shahzadi et al., 2005). Menurut Matz (1972) cit. Shahzadi et al. (2005), peningkatan kadar protein berpengaruh pada peningkatan daya serap air.

Kadar protein eggurt-kedelai hitam $(33,06 \%)$ lebih tinggi $(\mathrm{P}<0,01)$ daripada eggurt-wijen $(23,46 \%)$ dan eggurt-kacang hijau $(21,64 \%)$. Kadar protein eggurt kering dipengaruhi oleh kadar protein bahan pengisi yang ditambahkan. Biji-bijian yang ditambahkan mengandung protein 22,37\% untuk wijen, 38,78\% untuk kedelai hitam, dan 27,38\% untuk kacang hijau. Kedelai hitam mengandung protein yang lebih tinggi daripada kacang hijau dan wijen.

Kadar lemak eggurt kering yang dihasilkan menunjukkan nilai yang cukup tinggi yaitu eggurtkacang hijau sebesar 6,63\%, eggurt-wijen sebesar $8,82 \%$, dan eggurt-kedelai hitam 9,13\%. Kadar lemak yang tinggi ini disebabkan oleh biji-bijian yang ditambahkan juga mengandung lemak yang tinggi yaitu kacang hijau sebesar 1,21\%, wijen $13,21 \%$, dan kedelai hitam 15,17\%.

Kadar laktosa antara eggurt-wijen, eggurtkedelai hitam, dan eggurt-kacang hijau tidak berbeda, yaitu $3,04 \%, 2,80 \%$, dan 2,91\%. Laktosa dimanfaatkan oleh bakteri selama proses fermentasi sebagai sumber karbon dan menghasilkan asam laktat yang menyebabkan penurunan nilai $\mathrm{pH}$ dan kenaikan keasaman. Tabel 5 menunjukkan tidak terdapat perbedaan nilai $\mathrm{pH}$ dan keasaman eggurtsereal kering.

\section{Sifat sensoris}

Penilaian terhadap suatu mutu produk pangan memiliki dua aspek yaitu penilaian pembedaan sifat sensoris dan penilaian sifat sensoris atau intensitas mutu secara keseluruhan. Konsumen pada umumnya akan memilih produk yang terbaik dan disukai. Produsen dapat menguji produk-produk yang tersedia dengan uji organoleptik. Penilaian organoleptik merupakan suatu cara penilaian yang paling sederhana, karena penilaian ini menggunakan indera manusia secara langsung, namun demikian penilaian dengan menggunakan indra, banyak digunakan untuk menilai mutu komoditas hasil pertanian dan makanan. Hasil analisis rerata skor uji sensoris eggurt kering tersaji pada Tabel 3.

Dalam perkembangannya, dunia industri makanan banyak menggunakan cara ini untuk menilai dan menganalisis suatu produk yang dihasilkan, sehingga diharapkan dari hasil uji organoleptik tersebut dapat diketahui kekurangan serta langkah perbaikannya dari produk tersebut sampai produk layak untuk dipasarkan dan diterima oleh konsumen. Tabel 3 menunjukkan bahwa eggurt-wijen kering mempunyai daya terima yang lebih tinggi jika dibandingkan dengan eggurt-kedelai hitam dan eggurt-kacang hijau kering. Sifat sensoris erat kaitannya dengan kandungan lemak terutama asam lemak tidak jenuh yang terkandung dalam suatu bahan. Eggurt-wijen mempunyai daya terima yang paling tinggi karena biji wijen kaya akan asam lemak tak jenuh, khususnya asam oleat (C18:1) dan asam linoleat (C18:2, Omega-6), 8-10\% asam lemak jenuh, dan sama sekali tidak mengandung asam linolenat (Nzikou et al., 2009).

Berdasarkan Tabel 3, eggurt wijen kering mempunyai daya terima yang tinggi karena tingkat kemanisannya sedang, agak asam dan teksturnya agak keras. Kombinasi rasa ini lebih dapat diterima oleh konsumen pada umumnya. Selain pengaruh penambahan biji-bijian, aroma dan rasa eggurt bijibijian kering tersebut juga ditimbulkan oleh produk hasil proses fermentasi seperti asam laktat, asetaldehid, diasetil, dan asam asetat. Selama pemeraman (inkubasi) akan timbul senyawa-senyawa asam laktat, asetaldehida, diasetil, asam asetat, dan senyawa-senyawa yang mudah menguap yang dihasilkan oleh BAL. Senyawa-senyawa tersebut akan memberikan cita rasa spesifik pada eggurt. Rasa eggurt kacang hijau, wijen, dan kedelai hitam dipengaruhi oleh beberapa faktor seperti senyawa kimia, suhu, dan interaksi komponen lainnya. Aroma atau flavour khas eggurt disebabkan oleh asam laktat dan senyawa asetaldehid, diasetil, asam asetat, dan bahan-bahan mudah menguap lainnya yang dihasilkan selama fermentasi oleh bakteri Lactobacillus bulgaricus, penyebab utama terbentuknya asetaldehid (Buckle et al., 1987). Bau dan rasa asam eggurt kering lemah dan tidak setajam bau dan rasa dari eggurt segar. Sebagian cita rasa pada eggurt ditentukan oleh asam volatil pembentuk bau dan rasa asam sebagai contoh asam asetat, asam format, asam propionat, dan asam butirat yang mempunyai sifat mudah menguap selama pengeringan.

\section{Kualitas mikrobiologis}

Total bakteri asam laktat. Total BAL untuk eggurt-wijen kering adalah 8,45 log CFU/g, eggurtkedelai hitam 9,10 log CFU/g, dan eggurt-kacang hijau 8,35 $\log \mathrm{CFU} / \mathrm{ml}$. Tabel 4 menunjukkan bahwa total BAL sebelum pengeringan untuk eggurt-kedelai hitam lebih tinggi jika dibandingkan dengan eggurt-wijen dan kacang hijau $(\mathrm{P}<0,05)$. Hal ini disebabkan oleh tingginya nilai nutrisi kedelai hitam dibandingkan dengan wijen dan kacang hijau. Menurut Fardiaz (1989), pertumbuhan bakteri dipengaruhi oleh nilai nutrisi pada medium pertumbuhan. Selama pengeringan, total BAL semua eggurt mengalami penurunan, 
Tabel 3. Nilai hasil uji sensoris eggurt kering (score of sensoric evaluation)

\begin{tabular}{|c|c|c|c|}
\hline $\begin{array}{l}\text { Parameter sensoris } \\
\text { (sensoric parameter) }\end{array}$ & $\begin{array}{c}\text { Eggurt-wijen } \\
\text { (sesame egghurt) }\end{array}$ & $\begin{array}{l}\text { Eggurt-kedelai hitam } \\
\text { (black soybean sesame) }\end{array}$ & $\begin{array}{l}\text { Eggurt-kacang hijau } \\
\text { (green bean sesame) }\end{array}$ \\
\hline Kemanisan (sweetness) & 3,50 & 3,46 & 3,63 \\
\hline Keasama & & $2,29^{\mathrm{a}}$ & \\
\hline Tekstur $(t$ & $3,00^{\mathrm{a}}$ & $3,67^{\mathrm{c}}$ & \\
\hline Daya terima (acceptance) & $3,00^{\mathrm{a}}$ & $3,17^{\mathrm{b}}$ & $3,58^{\mathrm{c}}$ \\
\hline \multicolumn{4}{|c|}{$\begin{array}{l}\text { a,b,c Superskrip yang berbeda pada baris yang sama menunjukkan perbedaan }(\mathrm{P}<0,01) \text { (different superscripts } \\
\text { at the same row indicate significant differences }(P<0.01)) \text {. }\end{array}$} \\
\hline \multicolumn{4}{|c|}{$\begin{array}{l}1 \text { Skor kemanisan: } 1 \text { (sangat manis) - } 5 \text { (sangat tidak manis) (sweetness score: } 1 \text { (very sweet) - } 5 \text { (extremely not } \\
\text { sweet)) }\end{array}$} \\
\hline \multicolumn{4}{|c|}{ Skor keasaman: 1 (sangat asam) - 5 (sangat tidak asam) (acidity score: 1 (very acid) -5 (extremely not acid)) } \\
\hline \multicolumn{4}{|c|}{3 Skor tekstur: 1 (sangat keras) - 5 (lunak) (textur score: 1 (very hard) - 5 (soft)) } \\
\hline \multicolumn{4}{|c|}{$\begin{array}{l}\text { Skor daya terima: } 1 \text { (sangat disukai) - } 5 \text { (sangat tidak disukai) (acceptance score: } 1 \text { (highly accepted) - } 5 \\
\text { (extremely rejected)). }\end{array}$} \\
\hline
\end{tabular}

Tabel 4. Hasil rerata uji total bakteri eggurt (log CFU/g) (average of total bacteria of egghurt (log CFU/g))

\begin{tabular}{lcc}
\hline \hline & $\begin{array}{c}\text { Sebelum pengeringan } \\
\text { (before drying) }\end{array}$ & $\begin{array}{c}\text { Setelah pengeringan } \\
\text { (after drying) }\end{array}$ \\
\hline Eggurt-wijen (sesame eggurt) & $8,45^{\mathrm{xb}}$ & $5,67^{\mathrm{yc}}$ \\
Eggurt-kedelai hitam (black soybean eggurt) & $9,10^{\mathrm{xc}}$ & $5,35^{\mathrm{yb}}$ \\
Eggurt-kacang hijau (green bean eggurt) & $8,35^{\mathrm{xa}}$ & $5,16^{\mathrm{ya}}$ \\
a,b,c Superskrip yang berbeda pada kolom yang sama menunjukkan perbedaan $(\mathrm{P}<0,05)($ different superscripts \\
at the same column indicate significant differences $(P<0.05)$ ). \\
Superskrip yang berbeda pada baris yang sama menunjukkan perbedaan $(\mathrm{P}<0,05)($ different superscripts \\
at the same row indicate significant differences $(P<0.05))$.
\end{tabular}

namun total BAL pada eggurt-kedelai hitam menurun lebih banyak daripada eggurt-wijen dan eggurt-kacang hijau. Penurunan total BAL ini dipengaruhi oleh suhu dan lama pengeringan dan juga konsistensi bahan yang dikeringkan. Eggurt-wijen dan kacang hijau relatif lebih baik dalam mempertahankan total BAL jika dibandingkan dengan eggurt-kedelai hitam. Silliker et al. (1980) mengatakan bahwa konsistensi bahan sebagai medium akan mempengaruhi ketahanan bakteri terhadap tekanan dari lingkungan, misalnya suhu dan lama prosesing.

Nilai pH dan keasaman. Nilai $\mathrm{pH}$ dan keasaman merupakan parameter untuk menentukan hasil fermentasi produk. Aktivitas BAL selama fermentasi mempunyai korelasi yang positif terhadap penurunan $\mathrm{pH}$ dan peningkatan keasaman. Susu sapi mengandung kasein dan laktosa yang dapat digunakan oleh $L$. bulgaricus dan $S$. thermophillus sebagai sumber karbon dan energi untuk pertumbuhannya. Laktosa dihidrolisis menjadi asam piruvat dan selanjutnya asam piruvat tersebut oleh enzim laktat dehidrogenase diubah menjadi asam laktat. Asam laktat yang dihasilkan menyebabkan penurunan $\mathrm{pH}$ atau peningkatan keasaman. Protein utama susu yaitu kasein terpengaruh oleh perubahan $\mathrm{pH}$ dan keasaman, yaitu kasein menjadi tidak stabil ikatannya dan terkoagulasi membentuk curd yang kompak.

Hasil uji $\mathrm{pH}$ dan keasaman disajikan pada Tabel 5. Jenis biji-bijian, yaitu wijen, kedelai hitam dan kacang hijau yang ditambahkan dalam pembuatan eggurt kering tidak mempengaruhi nilai $\mathrm{pH}$ dan keasaman. Pada umumnya susu fermentasi mempunyai nilai pH sekitar 4,3-4,5. Hasil penelitian yang dilakukan oleh Andriani dan Khasanah (2010) menunjukkan bahwa susu fermentasi yang ditambah dengan umbi-umbian sebelum fermentasi mempunyai nilai $\mathrm{pH}$ 3,8-4,2 dan keasaman 0,66$0,99 \%$, sedangkan tanpa penambahan bahan lain $\mathrm{pH}$ 4,3 dan keasaman 1,24\%. Penambahan bahan pada pembuatan eggurt sesudah fermentasi dapat menyebabkan kenaikan nilai $\mathrm{pH}$ dan penurunan keasaman karena konsentrasinya menjadi tidak pekat. Eggurt biji-bijian kering memiliki nilai $\mathrm{pH}$ 5,005,11 . Nilai ini lebih tinggi daripada susu fermentasi yang tidak ditambahkan dengan putih telur dan bijibijian, yaitu 4,3-4,5. Tingginya nilai $\mathrm{pH}$ ini disebabkan oleh penambahan albumen dan biji-bijian giling. Nilai pH albumen adalah 9,6 (Stadelman dan Cotterill, 1995) dan nilai pH biji-bijian adalah sebesar 6,72 untuk wijen, 6,40 untuk kedelai hitam, dan 6,45 untuk kacang hijau sehingga jika 
Tabel 5. Rerata hasil uji nilai $\mathrm{pH}$ dan keasaman eggurt sereal kering (average of $\mathrm{pH}$ and degree of acidity of dried eggurt)

\begin{tabular}{lccc}
\hline \hline \multicolumn{1}{c}{ Parameter } & $\begin{array}{c}\text { Eggurt-wijen } \\
(\text { sesame eggurt) }\end{array}$ & $\begin{array}{c}\text { Eggurt-kedelai hitam } \\
\text { (black soybean eggurt) }\end{array}$ & $\begin{array}{c}\text { Eggurt-kacang hijau } \\
\text { (green bean eggurt) }\end{array}$ \\
\hline $\mathrm{pH}^{\mathrm{ns}}$ & 5,11 & 5,00 & 5,11 \\
Keasaman $\left(\right.$ acidity) $^{\mathrm{ns}}$ & 0,254 & 0,278 & 0,255 \\
\hline
\end{tabular}

${ }^{\mathrm{ns}}$ tidak terdapat perbedaan (non significant).

ditambahkan ke dalam eggurt akan menaikkan $\mathrm{pH}$ produk tersebut. Total asam tertitrasi eggurt kering adalah sebesar $0,25-0,28 \%$ asam laktat. Nilai keasaman yang rendah ini karena adanya penambahan biji-bijian kedalam eggurt.

\section{Kesimpulan}

Hasil penelitian dapat disimpulkan bahwa eggurt-wijen memiliki kualitas sensoris dan mikrobiologis yang paling tinggi, sedangkan kualitas kimia yang paling tinggi adalah eggurt-kedelai hitam.

\section{Daftar Pustaka}

Anonimus. 2009. Kacang Hijau. Available at http://www.plantamor.com. Accession date: 29 September 2009.

Anonimus. 2010. Kedelai Hitam yang Kaya Gizi. Available at http://rainbroccoli.wordpress. com/isen/si-hitam-yang-kaya-gizi/. Accession date: 2 Oktober 2010.

Andriani, M. dan L.U. Khasanah. 2010. Kajian karakteristik fisiko kimia dan sensori yoghurt dengan penambahan ekstrak ubi jalar (Ipomoea batatas L). Biomedika 3(1): 23-32.

Astawan, M. 2009. Sehat dengan Hidangan Kacang dan Biji-bijian, Penebar Swadaya, Jakarta.

Astuti, M. 1980. Rancangan Percobaan dan Analisa Statistik. Bagian 11. Fakultas Peternakan, Universitas Gadjah Mada, Yogyakarta.

Buckle, K.A., R.A. Edwards, G.H. Fleet, and M. Wooton. 1987. Food Science. Diterjemahkan dalam judul Ilmu Pangan oleh Hari Purnomo dan Adiono.1987. ed.1 UI Press, Jakarta.

Dadan. 2009. Manfaat Kacang Hijau. Available at http://www.indokul.co.cc/p=195. Accession date: 03 Juni 2009. Posted in: Health.
Fardiaz, S. 1989. Mikrobiologi Pangan. Institut Pertanian Bogor. Bogor.

Nzikou, J.M., L. Matos, G. Bouanga-Kalou, C.B. Ndangui, N.P.G. Pambou-Tobi, A. Kimbonguila, Th. Silou, M. Linder, and S. Desobry. 2009. Chemical composition on the seeds and oil of Sesame (Sesamum indicum L.) Grown in Congo-Brazzaville. Adv. J. Food. Sci. Tech. 1(1): 6-11.

Rybka, S. and Kailasapathy, K. 1996. Media for the enumeration of yoghurt bacteria. Int. Dairy Journal 6: 839-850.

Shahzadi, N., S.B. Masood, U.R. Saleem, and K. Sharif. 2005. Rheological and baking performance of composite flours. Int. J. Agric. Biol. 7(1): 100-104.

Silliker, J.H., A.C. Baird-Parker, F.L. Bryan, J.H.B. Christian, O.S. Clark, J.C. Olsony Jr., and T.A. Robert. 1980. Temperature. In: Microbial Ecology of Foods: Factors affecting life and death of microorganism. Academic Press, New York. Pp.1-37.

Susanto, T. dan B. Saneto. 1994. Teknologi Pengolahan Hasil Pertanian. ed.1. PT. Bina Ilmu. Surabaya.

Sudarmadji, S., Haryono, B., dan Suhardi. 1984. Prosedur Analisa untuk Bahan Makanan dan Pertanian. Liberty. Yogyakarta.

Stadelman, W.J., M. Olson, G.A. Shemwel, and S. Pasch. 1990. Egg and Poultry Meat Processing. VCH. Publ. Inc. USA.

Stadelman, W.J. and O.J. Cotterill. 1995. Egg Science and Technology. $4^{\text {th }}$ ed. Food Products Press. New York. London.

Tamime, A.Y. and R.K. Robinson. 1999. Yogurt : Science and Technology. $2^{\text {nd }}$ ed. Woodhead Publishing, Ltd. England. 